Emil W. Plywaczewski

\title{
GENEZA I STAN BADAŃ KRYMINOLOGICZNYCH NAD BEZPIECZEŃSTWEM W POLSCE
}

Pierwsze badania kryminologiczne nad bezpieczeństwem, zwłaszcza w aspektach związanych z przestępczością zorganizowaną, zostały zainicjowane w związku z powołaniem na Wydziale Prawa w Białymstoku w 1994 r., jeszcze w ramach Filii Uniwersytetu Warszawskiego, Zakładu Kryminologii i Problematyki Przestępczości Zorganizowanej. W Zakładzie tym prowadzonych było wiele inicjatyw naukowo-badawczych, które zaowocowały licznymi publikacjami ${ }^{1}$, w tym także rozpraw doktorskich i habilitacyjnych. Wiele tematów badawczych z tego zakresu zostały już sfinalizowanych, m.in. w ramach zakończonych przewodów doktorskich, inne są nadal prowadzone ${ }^{2}$.

W pierwszej kategorii mieszczą się takie problemy, jak zorganizowana przestępczość narkotykowa, przestępczość zorganizowana i jej zwalczanie w Polsce, korupcja w Policji, rozboje drogowe jako przejaw przestępczości zorganizowanej, problematyka świadka koronnego, zorganizowana przestępczość finansowa ze szczególnym uwzględnieniem procederu prania brudnych pieniędzy, kłusownictwo leśne czy wybrane aspekty pracy operacyjnej. W bieżącym roku została sfinalizowana rozprawa doktorska ${ }^{3}$, w której poddano analizie problem bezpieczeństwa wschodniego odcinka granicy Polski pod względem zagrożenia przestępczością graniczną cudzoziemców. Wskazano dynamikę i strukturę zjawiska w latach 1990-

Zob. m.in. P. Hofmański (red.), Z problematyki prawa karnego, Białystok 1994; Prawo karne i proces karny wobec nowych form i technik przestępczości (red. Piotr Hofmański, Hans Joachim Hirsch, Emil W. Pływaczewski i Claus Roxin), Białystok 1997, s. 527; Aktualne problemy prawa karnego i kryminologii (Current Problems of the Penal Law and Criminology; Aktuelle Probleme des Strafrechts und der Kriminologie), red. Emil W. Pływaczewski, Białystok 1998, s. 622; K. Laskowska, Nielegalny handel narkotykami w Polsce, Białystok 1999; Z. Rau, Przestępczość zorganizowana w Polsce i jej zwalczanie, Kraków 2002; E. Kowalewska-Borys, Świadek koronny w ujęciu dogmatycznym, Kraków 2004; W. Filipkowski, Zwalczanie przestępczości zorganizowanej w aspekcie finansowym, Kraków 2004; I. Nowicka, Rozbój drogowy jako przejaw przestępczości zorganizowanej, Kraków 2004; K. Laskowska, Rosyjskojęzyczna przestępczość zorganizowana. Studium kryminologiczne, Białystok 2006; S. Redo, Zwalczanie przestępczości zorganizowanej w Azji Centralnej, Warszawa 2007.

2 Szeroko na ten temat - zob. E.W. Pływaczewski, K. Laskowska, G. Szczygieł, E. Guzik-Makaruk, W. Filipkowski, E. Zatyka, Polskie kierunki badań kryminologicznych nad bezpieczeństwem obywateli, „Prokuratura i Prawo” 2010, nr 1-2. s. 176 i nast.

3 M. Perkowska, Kryminologiczne aspekty przestępczości cudzoziemców na wschodniej granicy Polski, Białystok 2011, maszynopis (s. 333). 
2010, jak również dokonano analizy systemu zwalczania przeciwdziałania przestępczości granicznej w systemie bezpieczeństwa państwa.

W kategorii uczelni resortowych dobrym przykładem w zakresach związanych z badaniami kryminologicznymi nad bezpieczeństwem jest także działalność naukowo-badawcza realizowana przez Wyższą Szkołę Policji w Szczytnie, w tym organizowanie seminariów i konferencji, na które zapraszani są przedstawiciele środowisk akademickich $^{4}$. W licznych tego typu inicjatywach, łącznie z realizowanymi projektami badawczymi brali też udział przedstawiciele Zakładu Kryminologii i Problematyki Przestępczości Zorganizowanej (później przekształconego na Zakład Prawa Karnego i Kryminologii) Uniwersytetu w Białymstoku.

Warto w tym miejscu wspomnieć o szczególnie ważnej imprezie naukowej poświęconej nowym zjawiskom kryminalnym w Polsce, jaka została zorganizowana z inicjatywy Fundacji Przeciwdziałania Przestępczości Zorganizowanej im. G. Falcone. Była to międzynarodowa konferencja naukowa na temat „Prawne aspekty nadużyć popełnianych z wykorzystaniem nowoczesnych technologii przetwarzania informacji"s. Współorganizatorami konferencji były Towarzystwo Naukowe Organizacji i Kierownictwa - Dom Organizatora w Toruniu, Wyższa Szkoła Policji w Szczytnie, Fundacja Przeciwdziałania Przestępczości Komputerowej oraz Biuro do Walki z Przestępczością Zorganizowaną Komendy Głównej Policji. Konferencja odbywała się pod auspicjami Rady Europy i patronatem Wiceprezesa Rady Ministrów, Ministra Sprawiedliwości i Prokuratora Generalnego RP Włodzimierza Cimoszewicza. ${ }^{6}$

Konferencja ta zapoczątkowała w Polsce publiczną dyskusję na temat zagrożeń dla różnego rodzaju dóbr prawnych, jakie niesie za sobą zjawisko komputeryzacji. Dokonano oceny aktualnego stanu rozwiązań prawnych w zakresie przeciwdziałania nadużyciom komputerowym oraz projektowanych zmian ustawodawczych w tej dziedzinie na tle europejskich standardów normatywnych. Przedstawiciele polskich firm komputerowych i sektora bankowego zastali zapoznani z doświadczeniami zachodnioeuropejskimi w zakresie skutecznego zwalczania piractwa softwarowego oraz ochroną systemów bankowych przed nadużyciami komputerowymi. Przedyskutowano też zasady ochrony prawnej informacji biznesowej oraz danych

$4 \quad$ Zob. m.in. Kryminologiczne i prawne aspekty przestępczości zorganizowanej. Studia i materiały, pod red. A. Marka i W. Pływaczewskiego), Szczytno 1992; S. Lelental, Raport końcowy z realizacji prac badawczych w ramach projektu badawczego „Przestępczość zorganizowana. Fenomenologia. Obszary występowania. Zwalczanie. Adekwatność unormowań prawnych”, „Przegląd Policyjny” 1996, nr 1, s. 71 i nast.; Kryminalistyczne i prawne problemy współczesnej przestępczości. Studia i materiały, pod red. S. Lelentala i M. Zajdera, Szczytno 1995; Policja Europy XXI wieku - w kierunku jakości. Materiały pokonferencyjne, pod red. A. Letkiewicza i W. Pływaczewskiego, Szczytno 2003).

5 Poznań, 20-22 kwietnia $1994 \mathrm{r}$.

6 Zob. Prawne aspekty nadużyć popełnianych z wykorzystaniem nowoczesnych technologii przetwarzania danych. Legal Aspects of Computer-Related Abuse. Materiały z Konferencji Naukowej, Poznań - Poland 20-22 kwietnia, pod red. A. Adamskiego, Toruń 1994, s. 389. 
osobowych na tle ustawodawstwa polskiego i projektów nowych aktów prawnych. Jednocześnie sformułowane zostały wnioski i zalecenia praktyczne z konferencji obejmujące fenomenologię nadużyć komputerowych w Polsce, relacje pomiędzy komputeryzacją a prawem, aspekty międzynarodowe, prawo karne materialne i procesowe, ochronę programów komputerowych i zwalczanie piractwa, ochronę informacji bankowej oraz ochronę danych osobowych.

W kolejnej fazie nastąpiło przejście do badań związanych z bezpieczeństwem o charakterze skoordynowanym. Za ich początek należy uznać projekt promotorski ${ }^{7}$, który zakończył się 30 listopada 2001 r. obroną na Wydziale Prawa Uniwersytetu w Białymstoku rozprawy doktorskiej Zbigniewa Rau pt. „Przestępczość zorganizowana w Polsce i jej zwalczanie". ${ }^{8}$ Prowadzone w ramach tego projektu badania dały asumpt do podjęcia przez różne środowiska - naukowe, organy ścigania i wymiaru sprawiedliwości - wspólnego wyzwania, jakim jest połączenie osiagnięć wiedzy naukowej z codzienną praktyką stosowania prawa i funkcjonowania organów państwa dla wspólnego dobra. Zostało bowiem potwierdzone, że najbardziej efektywną płaszczyzną współpracy interesującej nas sfery teorii i praktyki jest wspólne prowadzenie badań przez przedstawicieli szeroko rozumianej nauki prawa karnego i kryminologii oraz praktyki organów ścigania i wymiaru sprawiedliwości.

Sztandarowym przykładem wspólnego prowadzenia badań przez przedstawicieli szeroko rozumianej nauki prawa karnego i kryminologii oraz praktyki organów ścigania i wymiaru sprawiedliwości może być realizacja największego dotychczas w naukach społecznych projektu badawczego ${ }^{9}$ pt. , Rozwiązania prawne i organizacyjno-techniczne w zwalczaniu przestępczości zorganizowanej oraz terroryzmu ze szczególnym uwzględnieniem problematyki dowodów procesowych oraz instytucji świadka koronnego". Obejmował on zakrojone na szeroką skalę badania dotyczące w szczególności problematyki przestępczości zorganizowanej, terroryzmu oraz instytucji świadka koronnego ${ }^{10}$. Badania te zakończone zostały $\mathrm{z}$ końcem grudnia 2006 r. Na początku w poszczególnych zespołach badawczych funkcjonowało 40 uczestników, w końcowej zaś fazie realizacji projektu liczba ta wzrosła do 120 .

W oparciu o wyniki badań przeprowadzonych w ramach wyżej wymienionego projektu ważnym etapem omawiania strategicznej koncepcji współpracy podmiotów wymiaru sprawiedliwości i służb podlegających MSWiA z jednostkami badawczymi stanowiła międzynarodowa konferencja pt. „The Use of Modern Scientific Methods to Support Managing the Public Security in the European Union", któ-

$7 \quad \mathrm{Nr} 5$ H02A 01820.

$8 \quad$ Promotorem tej rozprawy był prof. zw. dr hab. Emil W. Pływaczewski. Wspomniana rozprawa została opublikowana: zob. Z. Rau, Przestępczość zorganizowana w Polsce i jej zwalczanie, Kraków 2002, s. 423.

9 Zamówionego przez Ministerstwo Nauki i Informatyzacji Nr PBZ-MIN-004/T00/2002.

10 Zob. E.W. Pływaczewski, Przestępczość zorganizowana. Świadek koronny. Terroryzm. W ujęciu praktycznym, Kraków 2005. 
ra została zorganizowana w Poznaniu w dniach 9-11 maja 2005 roku pod patronatem Komendanta Głównego Policji przy współudziale Politechniki Poznańskiej, Uniwersytetu w Białymstoku, Uniwersytetu im. Adama Mickiewicza w Poznaniu, Akademii Ekonomicznej w Poznaniu, Akademii Górniczo-Hutniczej w Krakowie oraz Politechniki Gdańskiej. Podczas konferencji podpisano porozumienie o powołaniu „Naukowej Sieci Uniwersyteckiej - POLSKIEJ PLATFORMY BEZPIECZEŃSTWA WEWNĘTRZNEGO" (PPBW), w celu wzmocnienia współpracy pomiędzy sektorami nauki, badań, rozwoju oraz edukacji w zakresie bezpieczeństwa publicznego. Polska Platforma Bezpieczeństwa Wewnętrznego powstała jako instytucja stawiająca sobie za cel tworzenie nowoczesnych narzędzi technologicznych, które będą istotnym wsparciem dla służb i instytucji odpowiedzialnych za porządek prawny i bezpieczeństwo obywateli. Słowo ,platforma” przyjmuje w tym przypadku znaczenie płaszczyzny, na której odbywa się wspólne realizowanie projektów, gdzie doświadczenie i praktyka idą w parze w z nowoczesnością.

Kolejny projekt PPBW pt. „Monitoring, identyfikacja i przeciwdziałanie zagrożeniom bezpieczeństwa obywateli" został realizowany w latach 2007-2010 w ramach umowy konsorcjum przez Uniwersytet w Białymstoku oraz Wojskową Akademię Techniczną ${ }^{11}$. Efekty przeprowadzonych w jego ramach prac naukowobadawczych mają duże znaczenie dla bezpiecznego rozwoju cywilizacyjnego RP, gdyż zaowocowały praktycznym zastosowaniem wyników badań w obszarze bezpieczeństwa państwa i jego obywateli.

Ogólnym celem projektu było przedstawienie organom państwa prototypowych rozwiązań w zakresie identyfikacji zagrożeń bezpieczeństwa obywateli, ich ostrzegania, a także kierowania bezpieczeństwem państwa. Projekt obejmował również przedstawienie pilotowych instalacji eksperckich narzędzi wspomagania decyzji w zakresie kierowania w sytuacjach kryzysowych, a także sieciowego systemu monitoringu, pozyskiwania i przetwarzania danych na rzecz ostrzegania o zagrożeniach i przeciwdziałania skutkom sytuacji kryzysowych. Interdyscyplinarny charakter projektu sprawił, iż wypełnił on zapotrzebowanie państwa na kompleksowy system wspomagania kierowania bezpieczeństwem państwa, obejmując takie obszary naukowe jak: politologia, ekologia, ekonomia, prawo, meteorologia, fizyka, elektronika, optoelektronika, chemia, informatyka, biologia, zarządzanie i wiele szczegółowych metod i technik, w tym z zakresu badań operacyjnych, sztucznej inteligencji, detekcji i identyfikacji zagrożeń.

Niezmiernie istotnym elementem założonych badań było to, iż w ich realizacji wzięli udział - obok przedstawicieli środowiska akademickiego - praktycy, tj. po-

11 Zob. E.W. Pływaczewski, Główne założenia i dotychczasowa realizacja projektu badawczego pt. Monitoring, identyfikacja i przeciwdziałanie zagrożeniom bezpieczeństwa obywateli, (w:) Praktyczne elementy zwalczania przestępczości zorganizowanej i terroryzmu. Nowoczesne technologie i praca operacyjna, red. L. Paprzycki, Z. Rau, Warszawa 2009, s. 677 i nast. 
licjanci, sędziowie oraz prokuratorzy, którzy na co dzień zajmują się zwalczaniem tych zjawisk. Dowodzi to praktycznej i bezpośredniej przydatności uzyskanych efektów badań oraz potrzeby czy wręcz konieczności ich użycia do podniesienia skuteczności działań organów ścigania. Realizacja zadań badawczych założonych w projekcie została podzielona pomiędzy Uniwersytet w Białymstoku oraz Wojskową Akademię Techniczną. Uniwersytet w Białymstoku zrealizował następujące zadania badawcze:

1. Problematyka procesowego dowodzenia przestępstw związanych $\mathrm{z}$ bezpieczeństwem systemów informacyjnych i ich wykorzystania w cyberprzestrzeni.

2. Problematyka efektywnego operacyjnego i procesowego wykorzystania systemów bezzałogowych przez organy ścigania.

3. Opracowanie nowych rozwiązań organizacyjnych i prawnych w celu zapewnienia przestrzegania prawa i dowodzenia przestępstw popełnianych przez funkcjonariuszy organów ścigania i wymiaru sprawiedliwości (korupcja itp.).

4. Zagrożenia związane z terroryzmem i cyberterroryzmem,

5. Diagnoza korzystania z Internetu przez zorganizowane grupy przestępcze, oraz

6. Wykorzystanie nowych technologii i rozwiązań prawnych przez organy ścigania.

Zadania badawcze zrealizowane przez Wojskową Akademię Techniczną obejmowały natomiast:

1. Zarządzanie kryzysowe w państwie.

2. Systemy wczesnego ostrzegania o sytuacji kryzysowych.

3. Bezpieczeństwo systemów informacyjnych w cyberprzestrzeni.

4. Materiał, podzespoły, sensory i struktury do systemów bezpieczeństwa, oraz

5. Zarządzanie bezpieczeństwem organizacji.

W ramach dotychczasowych działań Polskiej Platformy Bezpieczeństwa Wewnętrznego zorganizowano wiele ogólnopolskich konferencji i seminariów naukowych, w tym:

1. Konferencję nt.: „Prawo dowodowe a współczesne osiagnięcia informatyczne. Przestępczość zorganizowana. Terroryzm. Świadek koronny", 24 -28.X. 2005 r., Pałac Polskiej Akademii Nauk w Będlewie k/Poznania. 
2. Seminarium szkoleniowe Polskiej Platformy Bezpieczeństwa Wewnętrznego. Poznańskie Centrum Superkomputerowo-Sieciowe, 2.III.2006 r., Poznań.

3. Seminarium koordynatorów zespołów badawczych, 7 - 9.III.2006 r., Akademia Górniczo-Hutnicza w Krakowie.

4. Konferencję pt.: „Konwergencja projektów PPBW z założeniami 7 Programu Ramowego", 4-6 czerwca 2006 r., Dom Pracy Twórczej Polskiej Akademii Nauk w Wierzbie k/ Rucianego-Nida.

5. Konferencję pod Honorowym Patronatem I Prezesa Sądu Najwyższego nt. „Problematyka dowodowa przestępstw o charakterze terrorystycznym oraz efekty czynności o charakterze operacyjnym”, 6.IX.2006 r, Sąd Najwyższy, Warszawa $^{12}$.

6. Międzynarodową Konferencję nt. „Aspekty zarządzania bezpieczeństwem w Polsce i w krajach Unii Europejskiej w ujęciu prawnym, kryminologicznym oraz organizacyjno-technicznym"13, 5-8.XII.2006 r., Pałac Polskiej Akademii Nauk w Będlewie k/Poznania.

7. Seminarium kierowników projektów badawczych Polskiej Platformy Bezpieczeństwa Wewnętrznego, MSW - 20 czerwca 2007 r.

8. Konferencję nt. Kierunki działań antykorupcyjnych w organach administracji państwowej" (pod honorowym patronatem Rektora Akademii Ekonomicznej), Poznań, 25-27 czerwca 2007 r.

9. Konferencję nt. „Bezpieczeństwo i rozwój gospodarczy Państwa w obszarze nowoczesnych technologii”, pod patronatem Pierwszego Prezesa Sądu Najwyższego, Gmach Sądu Najwyższego, Warszawa 25 września 2009 r.

10. Konferencję nt. „Bezpieczeństwo - Innowacyjność - Gospodarka”, pod patronatem Dyrektora Gdańskiego Parku Naukowo-Technologicznego", Jurata, 26-28. sierpnia 2009 r.;

11. Konferencję Uniwersytetu Białymstoku nt. "Prawo karne i kryminologia wobec współczesnych zjawisk społecznych oraz rozwoju technologicznego", Białowieża, 2-5 września 2009 r.

Bliżej B. Kurzępa, Konferencja nt. „Problematyka dowodowa przestępstw o charakterze terrorystycznym oraz efekty czynności operacyjnych”, „Prokuratura i Prawo” 2006, nr 11, s. 183 i nast.; Od Redakcji, O postępowaniu operacyjnym, „Prokurator” 2006, nr 4, s. 5 i nast.; Z. Rau, Kierunki działań uczestników Polskiej Platformy Bezpieczeństwa Wewnętrznego w zakresie podniesienia efektywności pracy operacyjnej, „Prokurator” 2006, nr 4, s. 16 i nast. criminological, organizational and technical approach”. 
12. Seminarium nt. przedsięwzięć w ramach projektu rozwojowego pt. „Przeciwdziałanie i zwalczanie przestępczości zorganizowanej i terroryzmu w warunkach bezpiecznego, przyśpieszonego rozwoju i zrównoważonego rozwoju społeczno-gospodarczego" oraz badań w ramach projektu badawczo-rozwojowego pt. „Prawne i kryminologiczne aspekty wdrożenia i stosowania nowoczesnych technologii służących ochronie bezpieczeństwa wewnętrznego", Delegatura CBA, Gdańsk, 3.12.2009 r.

13. Konferencję nt. „Komercjalizacja nauki - efektywne zarządzanie projektami jako wyzwanie dla sektora publicznego i prywatnego", Gdański Park Naukowo-Technologiczny, Gdańsk, 20 maja 2010 r. $^{14}$; oraz

14. Konferencję nt „Nowoczesne rozwiązania technologiczne i prawne, jako determinanty skuteczności organów ścigania i wymiaru sprawiedliwości w walce z przestępczością", pod patronatem Pierwszego Prezesa Sądu Najwyższego, Gmach Sądu Najwyższego, Warszawa, 20 października 2010 r.

Konferencje te umożliwiły m.in. swobodną dyskusję pomiędzy praktykami i teoretykami prawa z jednej strony a członkami poszczególnych grup badawczych z drugiej. W efekcie pierwszych z wymienionych spotkań złożono wnioski badawczo-rozwojowe do Ministerstwa Nauki i Szkolnictwa Wyższego. Wnioski te były pierwszym etapem prac poszczególnych zespołów badawczych wchodzących w skład PPBW. Aktualnie na ich realizację przyznane już zostały znaczne - jak na polskie warunki - środki finansowe.

Warto w tym miejscu skrótowo przybliżyć dotychczasowe osiagnięcia PPBW $^{15}$.

1. Przygotowanie i przedstawienie Parlamentowi RP projektu nowelizacji ustawy o świadku koronnym. W jego przygotowaniu brało udział środowisko naukowe, ale przede wszystkim praktycy. Ich ogromny wkład i krytyczne spojrzenie pozwoliło na stworzenie efektywnego narzędzia do walki z przestępczością zorganizowana, które na trwałe stało się częścią polskiego systemu prawa. Zmiany zostały wprowadzone nowelą z dnia 22 lipca 2006 r. $^{16}$

2. Od samego początku trwania prac parlamentarnych nad ustawą o czynnościach operacyjno-rozpoznawczych PPBW bierze w nich udział. Jest to związane z zakończonym w październiku 2010 r. zamawianym projektem

\footnotetext{
14 Dyskusja toczyła się m.in. w panelach nt. komercjalizacji nowoczesnych technologii oraz sprawności procesu komercjalizacji i finansowania transferów technologicznych.

15 Pełna lista projektów znajduje się na stornie internetowej http://www.ppbw.pl Zob. także E.W. Pływaczewski, Z. Rau, The Polish Platform for Homeland Security - a Pioneer Initiative for Up-to-date Security in The European Union, (w:) Current Problems of the Penal Law and Criminology. Aktuelle Probleme des Strafrechts und der Kriminologie", Edited by/Herausgegeben von Emil W. Pływaczewski, Białystok 2009, s. 445 i nast.

Dz.U. z 2006 r. Nr 149, poz. 1078.
} 
badawczym „Monitoring, identyfikacja i przeciwdziałanie zagrożeniom bezpieczeństwa obywateli". W jego ramach były prowadzone intensywne prace badawcze, w których brali udział nie tylko naukowcy, przedstawiciele organów ścigania i służb specjalnych, ale także prokuratorzy i sędziowie, którzy często w swojej pracy zawodowej stykają się z wynikami tych czynności w postępowaniu karnym. PPBW stała się - podobnie jak w przypadku ustawy o świadku koronnym - płaszczyzną wymiany opinii, zdań i pomysłów na uregulowanie tej bardzo istotnej kwestii na długo przed tym, nim stała się ona tematem dyskursu społecznego i medialnego.

3. Uczestnicy PPBW jako pierwsi - narażając się na krytykę określonych środowisk politycznych - dyskutowali nad założeniami teoretycznymi i przygotowali projekty regulacji prawnych dotyczących rozdziału stanowisk Ministra Sprawiedliwości i Prokuratora Generalnego.

4. W ramach PPBW po raz pierwszy w Polsce prowadzone zostały kompleksowe badania kryminologiczne, dogmatyczne oraz prawnoporównawcze dotyczące nowych i współczesnych zagrożeń bezpieczeństwa obywateli, takich jak finansowanie terroryzmu oraz pozbawianie sprawców owoców przestępstwa (art. 44 i 45 kk.), w szczególności zjawiska prania pieniędzy.

5. Prowadzone też były zakrojone na najszerszą jak dotąd w Polsce skalę nowatorskie badania ankietowe tymczasowo aresztowanych, skazanych, wychowawców oraz funkcjonariuszy Biura Ochrony Służby Więziennej oraz badania akt osobowych (A, B) skazanych.

6. Od wielu już lat obszarem szczególnego zainteresowania PPBW jest problem stosowania rozwiązań technologicznych w praktyce organów ścigania i wymiaru sprawiedliwości, np. przesłuchanie na odległość, elektroniczne akta, analiza kryminalna. Dzięki zaangażowaniu i współpracy ze strony przede wszystkim sędziów powstała ogromna, unikalna w skali światowej baza nagrań prawniczego języka polskiego, która pozwoliła na przygotowanie systemu automatycznego rozpoznawania mowy i przetwarzania jej na tekst. Należy zakładać, że to rozwiązanie już w najbliższej przyszłości może zrewolucjonizować czynności protokołowania w polskiej procedurze karnej.

7. PPBW, jako jedyna organizacja w Polsce stara się rozwijać w zakresie bezpieczeństwa tzw. technologie podwójnego zastosowania - służące także osobom słabo widzącym i niewidomym. Pomimo iż nie jest to w sposób bezpośredni związane $\mathrm{z}$ funkcjonowaniem organów ścigania $\mathrm{i}$ wymiaru sprawiedliwości, to nie można zaprzeczyć, że w ten sposób realizowane są istotne cele $\mathrm{w}$ zakresie przeciwdziałania różnym patologiom oraz wykluczeniu społecznemu. Między innymi prowadzone są prace badawcze z udzia- 
łem specjalnych ośrodków dla dzieci niewidomych i słabowidzących w Krakowie i Owińskach. Inicjatywa ta zyskała uznanie międzynarodowe, m.in. Przewodniczącego Parlamentu Europejskiego prof. Jerzego Buzka oraz uczestników III. Europejskiej Konferencji nt. Badań nad Bezpieczeństwem w 2008 r., w Paryżu ${ }^{17}$.

Polska Platforma Bezpieczeństwa Wewnętrznego stanowi jednolite spojrzenie na wszelkie prace badawcze i rozwojowe, które mają na względzie ogólne bezpieczeństwo i dobro publiczne. Nowoczesne technologie mają wspierać działania jednostek policji i innych służb czuwających nad bezpieczeństwem, a także wspomagać działania zapobiegające różnego rodzaju zagrożeniom oraz łamaniu obowiązującego prawa. Tego typu przedsięwzięcia, sprzyjające: „zaawansowanemu, technologicznemu wsparciu zarządzania bezpieczeństwem wewnętrznym, zwalczania terroryzmu i przestępczości zorganizowanej”, współgrają z założeniami Komisji Unii Europejskiej, realizując tym samym jej plan ramowy.

Według informacji pochodzących bezpośrednio od Policji i innych służb mundurowych, w celu sprawnego wykrywania działań przestępczych, odpowiedniego zabezpieczania dowodów przestępstw, a kończąc na możliwie szybkim procesie sądowym, konieczne jest doposażenie służb w nowoczesne narzędzia. W szczególności dotyczy się to narzędzi informatycznych i teleinformatycznych pozwalających na zwiększenie efektywności podejmowanych działań.

Działania podejmowane przez Polską Platformę Bezpieczeństwa Wewnętrznego (PPBW) możemy podzielić na trzy etapy. Pierwszy z nich dotyczy zapoznania się z potrzebami wymiaru spraw wewnętrznych, prokuratury oraz wymiaru sprawiedliwości w zakresie nowoczesnych technologii, które zwiększą efektywność i skuteczność służb, prokuratury i sądownictwa. Kolejny etap polega na wykorzystaniu bazy naukowo-badawczej do stworzenia odpowiednich prototypów, będących efektem poszczególnych badań. Ostatnią fazę prac PPBW stanowi poszukiwanie partnerów do współpracy wśród przedsiębiorców, którzy byliby w stanie wyprodukować określoną liczbę produktów i wprowadzić je do sektora gospodarczego.

Polska Platforma Bezpieczeństwa Wewnętrznego niewątpliwe wpisuje się i realizuje te działania. Wieloletnie prace poświęcone tworzeniu nowoczesnych narzędzi technologicznych oraz duże doświadczenie z zakresu komercjalizacji badań naukowych powoduja, że środowisko związane $\mathrm{z}$ PPBW jest jednym $\mathrm{z}$ liderów w działaniach zmierzających do znalezienia wspólnego mianownika dla nauki i biznesu. Znaczne zainteresowanie efektami podjętych prac pozwala na to, aby z ostrożnym optymizmem spoglądać na przyszłe wprowadzanie konkretnych produktów na rynek

17 Zob. E.W. Pływaczewski, Sprawozdanie z II Europejskiej Konferencji nt. badań nad bezpieczeństwem (Paryż, 29-30 września 2008 r.), „Prokuratura i Prawo” 2009, nr 6. 
polski i europejski. Warto też podkreślić, że członkowie Polskiej Platformy Bezpieczeństwa Wewnętrznego stanowili oficjalną delegację rządową RP na XII Kongresie Organizacji Narodów Zjednoczonych Zapobiegania Przestępczości i Wymiaru Sprawiedliwości w Republice Brazylii (Salvador), 12-19 kwietnia 2010 r. ${ }^{18}$.

PPBW może poszczycić się nie tylko teoretycznymi osiagnięciami naukowymi, ale także gotowymi produktami wspierającymi pracę organów ścigania i wymiaru sprawiedliwości. Na dzień dzisiejszy przygotowano oraz przekazano Komendzie Głównej Policji oraz Straży Granicznej nieodpłatnie licencje do następujących rozwiązań informatycznych:

1 System thumaczenia automatycznego z języka polskiego na język angielski oraz z języka angielskiego na język polski dedykowany dla potrzeb organów bezpieczeństwa publicznego.

2 System przetwarzania częściowo ustrukturyzowanych dokumentów SOMP.

3 System wyszukiwania $i$ wizualizacji wzorców występujacych $w$ danych MAMUT.

4 Zintegrowane środowisko wspomagania analizy kryminalnej LINK.

5 System analizy danych przy użciu sieci spolecznych KASS.

6 Inteligentny system monitorowania sieci Internet IBIS.

7 System monitorowania sieci P2P (Gnutella Edonkey Monitor).

8 AFIZ (Analizator Faktów i Zwiazków, modul Analiza Bilingów wersja 1.0).

9 Program komputerowy do monitorowania Internetu pod katem wyszukiwania zdarzeń przestępczych $w$ Internecie MPI.

Nowe technologie informatyczne są potencjalnie ogromną szansą w zapobieganiu przestępczości ${ }^{19}$ oraz zwalczaniu patologii kryminalnych, lecz badania same w sobie nie stanowią jednak rozwiązania problemu. Aby można było mówić o pełnej efektywności konkretnej technologii, musi ona zostać skorelowana $\mathrm{z}$ obowiązującymi standardami, wymogami prawnymi oraz uzyskać akceptację społeczną ${ }^{20}$. Powstają bowiem pytania, na ile konieczne są zmiany w prawie dopuszczające stosowanie nowych rozwiązań technicznych w celu przeciwdziałania najgroźniejszym formom przestępczości i w jakim stopniu poszerzenie uprawnień organów ścigania

18 Zob. E.W. Pływaczewski, Zapobieganie przestępczości i sprawiedliwość karna. XII Kongres Organizacji Narodów Zjednoczonych (Salwador, Brazylia,12-19 IV 2010), „Państwo i Prawo” 2010, nr 10, s. 133-135.

19 Szerzej - zob. J. Błachut, A. Gaberle, K. Krajewski, Kryminologia, Gdańsk 1999, s. 459 i nast.

20 Ostatnio zob. zwłaszcza: Obszar wolności, bezpieczeństwa i sprawiedliwości Unii Europejskiej. Geneza, stan i perspektywy rozwoju, pod red. F. Jasińskiego i K. Smoter, Warszawa 2005; Prawnokarne aspekty wolności. Materiały z Konferencji, Arłamów 16-18 maja 2005 r., pod red. M. Mozgawy, Kraków 2006: A. Sakowicz, Prawnokarne gwarancje prywatności, Kraków 2006. P. Girdwoyń (red.), Prawo wobec nowoczesnych technologii, Warszawa 2008. 
wpłynie na ochronę praw i wolności obywateli ${ }^{21}$. Zagadnienia te stały się ostatnio przedmiotem ożywionej dyskusji na Security Research Conference (Warszawa, 1921 września 2011 r. $)^{22}$.

21 Szerzej zob. S. Waltoś, Proces karny. Zarys systemu, LexisNexis, Warszawa 2009, s. 408 i nast.; L. Gardocki, J. Godyń, M. Hudzik, L.K. Paprzycki (red.), Nowe technologie dowodowe a proces karny. Konferencja Sędziów Izby Karnej i Izby Wojskowej Sądu Najwyższego, Warszawa 2007. Szczególnie interesujące z perspektywy nauki prawa karnego sa zawarte w tej pracy opracowania przedstawicieli nauk informatycznych profesora Ryszarda Tadeusiewicza, pt. „Nowe technologie dowodowe dla przestępstw popełnianych w obszarze Społeczeństwa informacyjnego", s. 19 i nast. oraz dr. Mikołaja Sobczaka pt. „Systemy mobilne” w służbie prawa, s. 21 i nast.

22 W ramach sesji nr 6 nt. „Security of Financial Operations - Advanced technologies for penal Procedure”, moderowanej przez piszącego te słowa. 


\section{ГЕНЕЗИС И СОСТОЯНИЕ КРИМИНОЛОГИЧЕСКИХ ИССЛЕДОВАНИЙ БЕЗОПАСНОСТИ В ПОЛЬШЕ}

В работе анализируется генезис криминологических исследований безопасности в Польше, а также описывается их современное состояние. Исследования в этой области были начаты в связи с созданием на Юридическом факультете в Белостоке в 1994 году Учреждения криминологии и проблематики организованной преступности. В этом учреждении предпринято много научно-исследовательских инициатив, которые принесли плоды в виде многочисленных публикаций, а также докторских и кандидатских диссертаций. На очередном этапе произошел переход к исследованиям координированного характера, связанным с безопасностью, которые проводились представителями науки уголовного права и криминологии, а также практическими работниками органов следствия и правосудия. Главным результатом этих исследований в национальном масштабе явилось создание, с целью укрепления сотрудничества между секторами науки, исследований, развития и просвещения в сфере общественной безопасности Научной университетской сети - ПОЛЬСКОЙ ПЛАТФОРМЫ ВНУТРЕННЕЙ БЕЗОПАСНОСТИ (ППВБ). ЭТа инициатива была направлена на соединение теории (юридической, криминологической, криминалистической, социологической, информационной и технологической) с практикой органов следствия и правосудия в сферах, относящихся к разным аспектам обеспечения безопасности граждан. Благодаря междисциплинарному характеру исследований их результаты удовлетворяют спрос государства на комплексную систему поддержки его безопасности, включая такие научные сферы, как политология, экономика, право, метеорология, физика, электроника, оптоэлектроника, химия, информатика, биология и менеджмент. Новые информационные технологии дают широкие перспективы в предупреждении преступности, в борьбе с криминальной патологией, а также в обеспечении критической инфраструктуры. Последний этап работ ППВБ - это поиски партнеров для сотрудничества среди предпринимателей, которые были бы в состоянии обеспечить производство определенного количества соответствующей продукции и ввести ее в хозяйственный сектор. В статье отмечаются многочисленные достижения в рамках этой уникальной инициативы мирового масштаба. 


\section{ORIGINS AND STATUS OF CRIMINOLOGICAL RESEARCH ON SAFETY IN POLAND}

The present study refers to the origins of criminological research concerning security in Poland and describes its current status. Research in this area was initiated in connection with the formation of the Department of Criminology and Organized Crime Issues in the Faculty of Law in Bialystok in 1994. Many initiatives and scientific studies, which resulted in numerous publications, including doctoral and post-doctoral (habilitation) theses, were conducted in the Department. This was followed by a new phase in the research programme concerning security of a coordinated character, carried out by representatives of the science of criminal law in the widest sense of the meaning and criminology and those involved in the practice of law enforcement and justice administration. The main result of these studies on a national scale was the establishment of a scientific network of universities POLISH PLATFORM of INTERNAL SECURITY (PPBW), in order to strengthen cooperation between the sectors of science, research, development and education within the scope of public security.

This initiative was aimed at combining theory (of law, criminology, criminalistics, social science, computer science and technology) with the practice of law enforcement and justice administration in areas relating to the various aspects of securing the safety for citizens. The interdisciplinary nature of the research means that the results fulfil the public demand for a comprehensive system supporting the administration of safety, covering such scientific areas as political science, ecology, economics, law, meteorology, physics, electronics, optoelectronics, chemistry, computer science, biology and management. New information technologies offer potentially vast opportunities in crime prevention and combating criminal pathology, as well as in ensuring the safety of vital components of infrastructure. The last phase of the PPBW's work is seeking partners for cooperation among entrepreneurs, who would be in a position to produce a certain number of products and introduce them to the economic sector. Numerous achievements of this unique worldwide initiative are highlighted in the present study.

Key words:

Administration of safety, scientific network, crime prevention, combating of criminal pathology, research 